\title{
Stimulation of immunoreactive inhibin production by preimplantation embryos during early pregnancy in the marmoset monkey (Callithrix jacchus)
}

\author{
G. E. Webley ${ }^{1}$, P. G. Knight ${ }^{2}$ and J. P. Hearn ${ }^{3}$ \\ ${ }^{1}$ MRC/AFRC Comparative Physiology Group, Institute of Zoology, Regent's Park, \\ London NWI 4RY, UK; ${ }^{2}$ Department of Biochemistry and Physiology, University of Reading, \\ Whiteknights, Reading RG6 2AJ, UK; and ${ }^{3}$ Wisconsin Regional Primate Research Center, \\ University of Wisconsin, Madison, Wisconsin, USA
}

\begin{abstract}
Summary. The role of the embryo in promoting increased plasma concentrations of immunoreactive inhibin after conception in the marmoset monkey was determined by flushing embryos from the uterus between days 5 and 9 after ovulation (implantation commences on days 11-12). Blood samples were taken from each animal (three times a week) after ovulation until the end of the luteal phase. Plasma inhibin concentrations were measured using a radioimmunoassay based on antisera against a synthetic fragment of the $\alpha$-subunit of human inhibin. When embryos were flushed on days 5 and 6 $(n=6)$ after ovulation inhibin concentrations did not exceed $250 \mathrm{ng} \mathrm{ml}^{-1}$ for the duration of the luteal phase. In contrast when embryos were flushed on days $7(n=4)$, $8(n=4)$ and $9(n=3)$ maximum concentrations of inhibin always exceeded $250 \mathrm{ng}$ $\mathrm{ml}^{-1}$, reaching $>400 \mathrm{ng} \mathrm{ml}^{-1}$ when embryos were flushed on days 8 and 9 . Inhibin concentrations remained high for the duration of the luteal phase, which varied in length between 20 and 32 days. Significantly $(P<0.01)$ higher mean plasma concentrations of immunoreactive inhibin were first recorded on days 7-8 after ovulation in animals that had embryos flushed on days 7,8 and 9 compared with concentrations in animals that had embryos flushed on days 5 and 6 . Inhibin could not be detected in the medium of embryos cultured for up to 2 weeks. In two control animals, inhibin concentrations exceeded $250 \mathrm{ng} \mathrm{ml}^{-1}$ after sham operation on day 6 , whereas inhibin did not exceed $250 \mathrm{ng} \mathrm{ml}^{-1}$ when unfertilized eggs were flushed from the uterus of an animal on day 8 after ovulation. Progesterone concentrations did not differ significantly among animals irrespective of the day of embryo flushing. The results suggest that the marmoset pre-implantation embryo provides a signal on days 7-8 which triggers an increase in luteal inhibin production. The continued presence of this putative signal was not necessary for maintaining increased inhibin production.
\end{abstract}

Key'words: embryo; inhibin; pregnancy; marmoset monkey

\section{Introduction}

Peripheral concentrations of immunoreactive inhibin increase in the luteal phase of the ovarian cycle in several primate species including women (McLachlan et al., 1987a), stumptailed macaque (Fraser et al., 1989) and marmoset monkeys (Smith et al., 1990; Webley et al., 1991). Comparison of the luteal increase in inhibin concentrations in conception versus nonconception cycles shows that the levels are significantly higher after conception in women (McLachlan et al., 1987b) and marmoset monkeys (Webley et al., 1991). 
A major source of inhibin in the conception and nonconception luteal phase of the primate appears to be the corpus luteum. Administration of a luteinizing-hormone-releasing hormone (LHRH) antagonist during the luteal phase of women (McLachlan et al., 1989), stumptailed macaques (Smith \& Fraser, 1991) and marmoset monkeys (Webley et al., 1991) was associated with a decrease in inhibin concentrations as well as progesterone concentrations. Lutectomy in the mid-luteal phase of cynomologous monkeys resulted in suppression of serum inhibin concentrations (Basseti et al., 1990). The human and marmoset corpus luteum contains mRNA for the $\alpha$ subunit of inhibin (Davis et al., 1987; Hillier et al., 1989). Furthermore, the marmoset corpus luteum has a high content of inhibin (about $100 \mathrm{ng} \mathrm{mg}^{-1}$; Knight et al., 1991) and human luteinized granulosa cells secrete inhibin in culture (Tsonis et al., 1987).

The corpus luteum may not be the only source of inhibin in pregnancy. In a study in which pregnancy was maintained in women with nonfunctional ovaries after oocyte donation, inhibin concentrations rose within 2-4 weeks of transfer and continued to increase during pregnancy (McLachlan et al., 1987c). Placental tissue contains mRNA for $\alpha$ and $\beta A$ subunits of inhibin (Mayo et al., 1986) and produces inhibin in vitro (Petraglia et al., 1987).

The timing of the increase in inhibin concentrations after conception differs in marmosets and humans. In the nonpregnant marmoset, inhibin concentrations reached a maximum value on days 12-13 after ovulation. In pregnant marmosets, inhibin concentrations were significantly higher than in nonpregnant animals on days 8 and 9 after ovulation, and continued to rise until at least days 20-21 after ovulation (Webley et al., 1991). The increase on day 8 occurred before implantation which commences on days 11-12 after ovulation (Moore et al., 1985) and preceded the first increase in chorionic gonadotrophin, which could not be detected in plasma until day 17 . In women, however, the first increase detected in plasma inhibin concentrations coincided with the time of implantation and the first increase in human chorionic gonadotrophin (hCG) concentrations such that a parallel rise in inhibin, hCG and progesterone concentrations was recorded after day 9 (McLachlan et al., 1987b).

The aim of the present study was to explore the role of the embryo in promoting the increased concentrations of inhibin after conception in the marmoset monkey. Two hypotheses were tested. (1) Does the early embryo itself produce inhibin and contribute to the increased peripheral concentrations? (2) Does the embryo provide a stimulus to increase luteal inhibin production and what is the precise timing of this stimulus?

\section{Materials and Methods}

\section{Animals and treatments}

Adult female marmoset monkeys of proven fertility were from a self-sustaining breeding colony maintained at the Institute of Zoology in family groups as described previously (Hearn, 1980). The marmoset has a 28 day cycle consisting of an 8-9 day follicular phase and a 19-20 day luteal phase (Harlow et al., 1983). Implantation starts on days 11-12 after ovulation (Moore et al., 1985). The onset of the ovarian cycle was controlled by administration of a single 0.5 $\mu \mathrm{g}$ i.m. injection of the prostaglandin $\mathrm{F}_{2 u}\left(\mathrm{PGF}_{2 u}\right)$ analogue, cloprostenol (estrumate: ICI Pharmaceuticals Division, Macclesfield, Cheshire, UK) (Summers et al., 1985). The day of ovulation was defined as the day preceding a rise in plasma progesterone concentrations $>10 \mathrm{ng} \mathrm{ml}^{-1}$ (Harlow et al., 1983).

Laparotomy was performed on animals anaesthetized with an i.m. injection of a steroid anaesthetic (Saffan, $1.0 \mathrm{ml}$ : Glaxo, Ware, Herts, UK). Embryos were flushed from the uterus, as described previously (Hearn et al., 1988), on days 5, 6, 7, 8 and 9 after ovulation. A total of 27 laparotomies were performed, although embryos were not retrieved from eight of these. Since it was not possible to determine whether these animals failed to conceive or whether the embryos were lost during the flushing procedure, these were excluded. A sham laparotomy was performed on one animal and unfertilized eggs were flushed from another. After laparotomy, blood samples were taken from the femoral vein three times per week from each animal until the end of the luteal phase. If the number of embryos recovered after flushing of the uterus was not equivalent to the number of corpora lutea, the nonpregnant state was confirmed by measurement of plasma chorionic gonadotrophin concentrations on day 18 after ovulation.

Ten embryos, obtained from the uterine flushes, were cultured individually in wells of 96 culture well plates

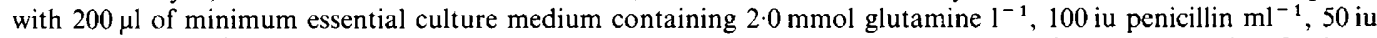
streptomycin $\mathrm{ml}^{-1}$ and $20 \%$ fetal calf serum. The medium was changed every $3-4$ days for up to 4 weeks of culture 
(at $37^{\circ} \mathrm{C}$ in a humidified atmosphere of $5 \% \mathrm{CO}_{2}$ in air) for estimation of immunoreactive inhibin and bioactive gonadotrophin concentrations. A total of 45 culture medium samples were assayed.

\begin{abstract}
Assays
Inhibin. Concentrations of immunoreactive inhibin were measured by radioimmunoassay as described previously (Webley et al., 1991). The assay uses an antibody raised in sheep against the amino-terminal sequence of the $\alpha$ subunit of human inhibin (Beard et al., 1990). Monomeric bovine $\alpha$ subunit and $32 \mathrm{kDa}$ bovine inhibin were used as tracer and standard, respectively.

The detection limit of the assay was $0.3 \mathrm{ng}$ per tube. Intra- and interassay coefficients of variation were 8.5 and $14.1 \%(n=7$ assays), respectively. The assay showed no detectable crossreaction with recombinant activin-A (generously supplied by Genentech Inc., San Francisco, CA, USA) but crossreacted extensively (about 300\%) with 'free' inhibin $\alpha$ subunit $\left(M_{\mathrm{r}} 25000\right)$ isolated from bovine follicular fluid (Knight et al., 1989).
\end{abstract}

Progesterone. Progesterone concentrations in marmoset plasma were measured using a direct enzyme immunoassay as described previously (Hodges et al., 1988). The sensitivity of the assay was $1 \cdot 1 \mathrm{ng} \mathrm{ml}^{-1}$ and intra- and interassay coefficients of variation were $<9 \%$ and $<16 \%$, respectively.

Gonadotrophin bioassay. Chorionic gonadotrophin was measured using an in vitro bioassay that is based on the production of testosterone by dispersed mouse Leydig cells (Van Damme et al., 1974) and has been validated for measurement of LH and CG in marmoset plasma (Hearn et al., 1988). The sensitivity of the assay varied between 8.4 and $14.1 \mathrm{iu} \mathrm{LH}]^{-1}$. Intra- and interassay coefficients of variation were $8.6 \%$ and $10 \cdot 1 \%$, respectively.

\title{
Analysis of data
}

From the previous study of immunoreactive inhibin concentrations in the luteal phase (Webley et al., 1991) maximum concentrations in nonpregnant animals reached $242 \pm 16 \mathrm{ng} \mathrm{ml}^{-1}$, whereas in pregnant animals concentrations rose to $636 \pm 141 \mathrm{ng} \mathrm{ml}^{-1}$. Maximum concentrations of inhibin exceeding $250 \mathrm{ng} \mathrm{ml}^{-1}$ were therefore considered to indicate conception. The animals were grouped according to the day of embryo flushing and compared between groups using the Fisher's exact test to establish whether the maximum concentration of inhibin exceeded $250 \mathrm{ng} \mathrm{ml}^{-1}$ in a significant number of the animals in each group. The mean inhibin concentrations grouped according to the day of embryo flushing for every 2 days of the cycle were compared at particular days after ovulation using Student's unpaired $t$ test.

\section{Results}

When embryos were flushed from the uteri of animals on days $5(n=3)$ and $6(n=3)$ after ovulation maximum plasma concentrations of inhibin did not exceed $250 \mathrm{ng} \mathrm{ml}^{-1}$ for the duration of the luteal phase (Fig. 1a). When embryos were flushed on day $7(n=4)$ after ovulation maximum concentrations of inhibin exceeded $250 \mathrm{ng} \mathrm{ml}^{-1}$ in all four animals but did not reach $400 \mathrm{ng} \mathrm{ml}^{-1}$ (Fig. 1b). Of those animals that had embryo flushes performed on day $8(n=4)$ after ovulation the maximum concentration of inhibin exceeded $250 \mathrm{ng} \mathrm{ml}^{-1}$ in three of four animals and exceeded $400 \mathrm{ng} \mathrm{ml}^{-1}$ in one of four (Fig. Ic). Concentrations of inhibin remained high for the duration of the luteal phase. When embryos were flushed on day $9(n=3)$ maximum concentrations of inhibin exceeded $400 \mathrm{ng} \mathrm{ml}^{-1}$ in all three animals (Fig. 1d). The higher inhibin concentrations recorded in these three animals showed a more precipitous drop at the end of the luteal phase than in other animals, but the length of the luteal phase fell within the same range. There was a significant difference $(P<0.05)$ in the number of animals with maximum concentrations of inhibin $>250 \mathrm{ng} \mathrm{ml}^{-1}$ when embryos were flushed on days 7,8 or 9 compared with flushes performed on days 5-6, but not when comparisons were made among flushes performed on days 7,8 and 9 after ovulation. There was no relationship between the number of corpora lutea, which varied in each animal between two and three, and the maximum concentrations of inhibin achieved after flushing (see legend to Fig. 1). The presence of the embryo therefore appeared to cause an increase in inhibin concentrations, which was prevented when embryos were flushed before day 7 .

The inhibin profiles (Fig. 2) show that mean inhibin concentrations after flushing embryos on days 7,8 and 9 after ovulation were higher than those after flushing embryos on days 5 and 6 . 


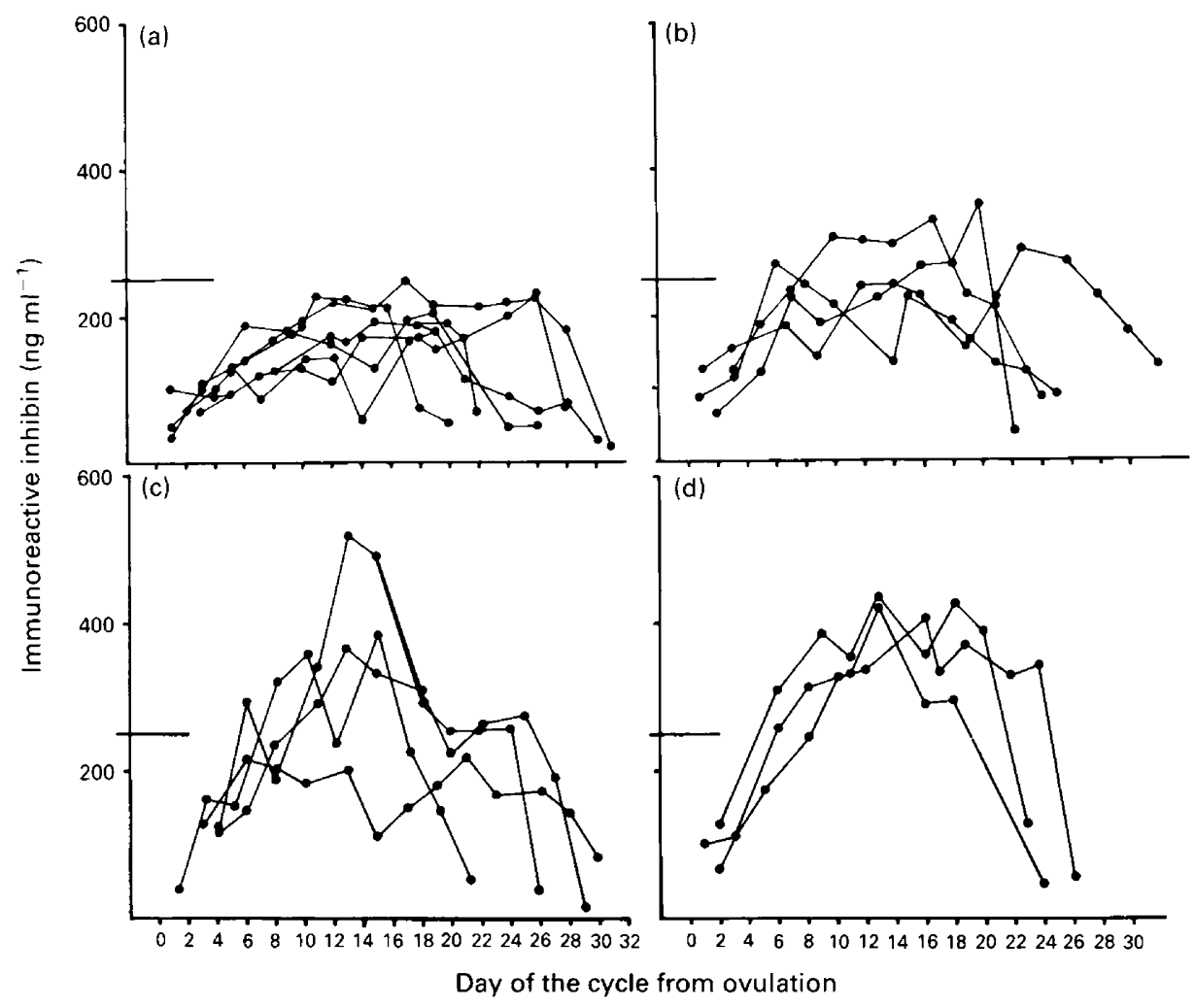

Fig. 1. Concentrations of immunoreactive inhibin in plasma samples from individual marmosets at different times in the cycle related to the day of ovulation and taken before and after embryos were flushed from the uterus on (a) days 5 and 6 after ovulation $(n=6 ; 4$ animals had 2 corpora lutea, 2 had 3 corpora lutea); (b) day $7(n=4 ; 2$ animals had 2 corpora lutea and 2 had 3) after ovulation; (c) day $8(n=4 ; 3$ animals had 2 corpora lutea and 1 had 2) after ovulation and (d) day $9(n=3 ; 1$ animal had 2 corpora lutea and 2 had 3$)$ after ovulation.

Day 7-8 after ovulation was the first time in the cycle when inhibin concentrations where significantly higher $(P<0.01)$ in animals that had embryos flushed on days 7,8 and 9 compared with those that had embryos flushed on days 5 or 6 . Inhibin could not be detected in any of the conditioned medium samples of embryos cultured for up to 4 weeks. The ability of the radioimmunoassay to measure inhibin in culture medium was confirmed by quantitative recovery of exogenous inhibin standard added to three representative embryo culture samples. The embryos grew well in culture, they attached to the culture wells and showed outgrowth and differentiation of trophoblast cells. An increase in bioactive gonadotrophin concentrations was detected in the embryo culture medium from the time of embryo attachment.

Plasma inhibin concentrations were measured after two control laparotomies. Inhibin concentrations after a sham operation on day 6 after ovulation exceeded $250 \mathrm{ng} \mathrm{ml}^{-1}$ and rose to a maximum of $625 \mathrm{ng} \mathrm{ml}^{-1}$ on day 24 before the pregnancy was terminated with cloprostenol on day 26 after ovulation. In contrast when unfertilized eggs were flushed from the uterus of an animal on day 8 after ovulation inhibin concentrations did not exceed $250 \mathrm{ng} \mathrm{m}^{-1}$ for the duration of the luteal phase (Fig. 3). The sham procedures do not therefore prevent increases in inhibin concentrations whereas the presence of unfertilized eggs had no stimulatory effect.

Irrespective of the day of embryo flushing, plasma progesterone concentrations measured in the same samples that were assayed for inhibin did not differ significantly among animals irrespective of the day of embryo flushing. Mean plasma progesterone concentrations (Fig. 4) are grouped for 


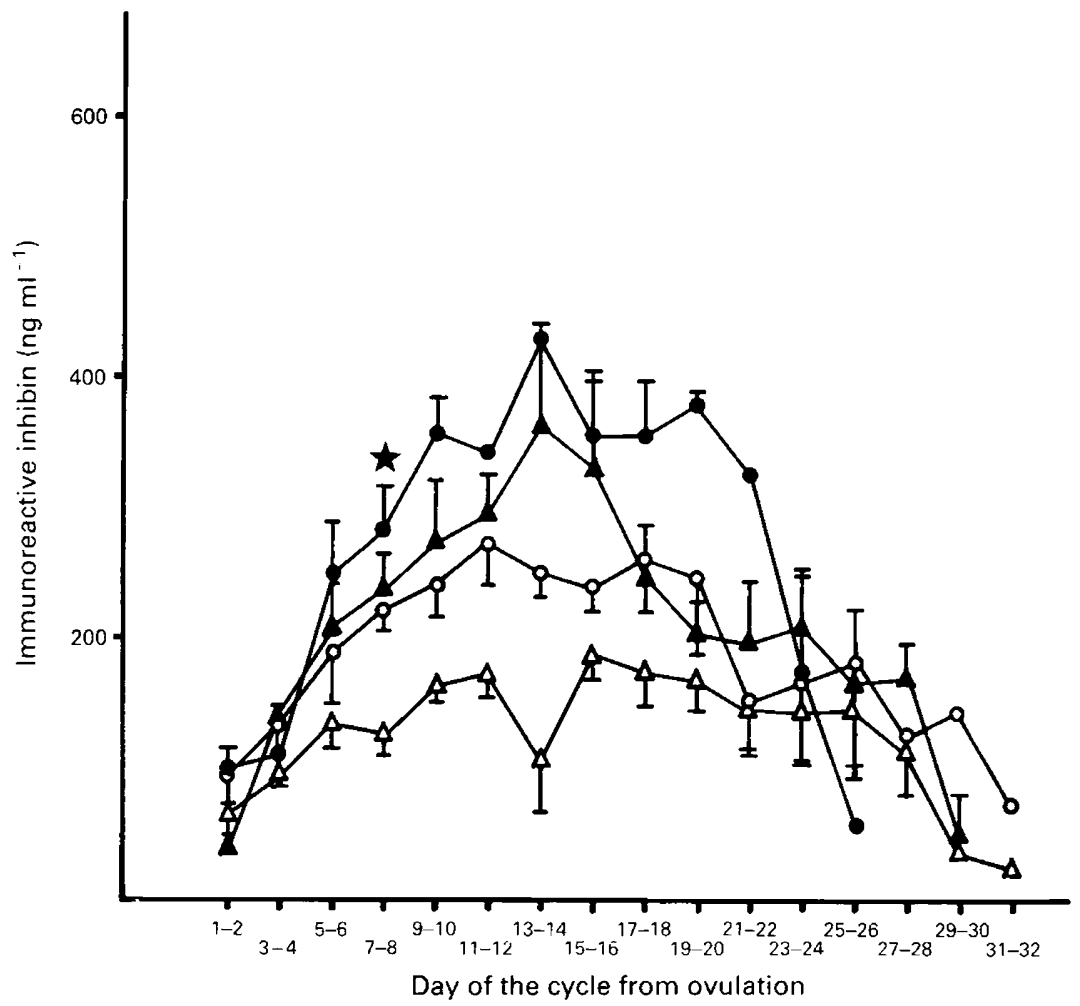

Fig. 2. Mean ( \pm SEM) concentrations of inhibin in plasma samples taken from marmosets after flushing embryos on days 5-6( $\triangle), 7(O), 8(\Delta)$ and $9(\mathbf{O})$ after ovulation, at different times in the cycle shown from the day of ovulation. $\star P<0.01$ first time in the cycle when inhibin concentrations in marmosets that had embryos flushed on days 7,8 or 9 after ovulation were significantly higher than those that had embryos flushed on days 5-6.

every 2 days of the cycle after ovulation. It was noted that the animals showed a wide variation in the duration of the luteal phase, estimated as the number of days with progesterone concentrations of $>10 \mathrm{ng} \mathrm{ml}^{-1}$, which ranged between 20 and 32 days.

\section{Discussion}

This study demonstrated a role for the marmoset embryo in promoting the increased plasma concentrations of immunoreactive inhibin that were reported earlier in the luteal phase of conception cycles of this new world primate (Webley et al., 1991). The embryo provides the stimulus on days 7 to 8 after conception, directly or indirectly stimulating an increase in luteal inhibin production.

Our results suggest that the embryo does not itself contribute substantially to the increased plasma concentrations of inhibin. It was not possible to detect inhibin production by embryos in culture. Furthermore, the high sustained concentrations of inhibin measured in plasma after removal of embryos on days 8 and 9 after ovulation suggested that any inhibin produced by the embryo would make only a very small contribution to the peripheral concentrations. We and others (see Introduction) have shown that the corpus luteum is a major source of inhibin in the primate luteal phase. However, a study by McLachlan et al. (1987c) in which pregnancy was maintained in three women with nonfunctional ovaries after oocyte donation suggested an 


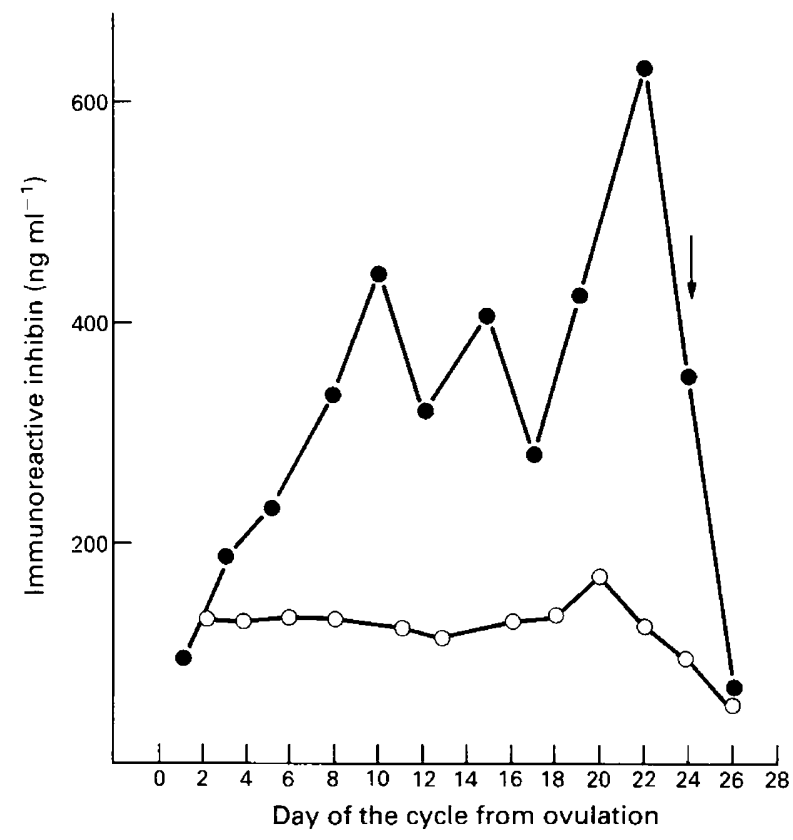

Fig. 3. Concentrations of inhibin in plasma samples from two control marmosets at different times in the cycle related to the day of ovulation. (-) sham laparotomy on day 6 after ovulation; ( $O$ ) unfertilized eggs flushed from the uterus on day 8 after ovulation. Arrow: administration of cloprostenol to sham-operated marmoset.

embryonic source for inhibin. Serum inhibin concentrations rose within 2-4 weeks of transfer and continued to increase during pregnancy. The biphasic pattern of inhibin reported during pregnancy in normal women (Abe et al., 1990; Tabei et al., 1991) suggests that the corpus luteum could be a major source in early gestation and that the placenta takes over production in the later part of pregnancy. The low concentrations of inhibin measured by McLachlan et al. (1987c) during early gestation in women with nonfunctional ovaries may represent the start of placental production but the high concentrations recorded in normal pregnant women at this time indicate a major luteal contribution in addition to that of placental origin.

The ability of marmoset embryos to provide a stimulus on days 7 to 8 after conception raises the question of the nature of this stimulus. Co-administration of hCG with an LHRH antagonist to women (McLachlan et al., 1989), macaques (Smith \& Fraser, 1991) and marmoset monkeys (Webley et al., 1991) prevented the decrease in inhibin concentrations resulting from administration of LHRH antagonist alone. This suggests that in these primate species inhibin secretion is under LH control and can be stimulated by hCG. A parallel increase in hCG, inhibin and progesterone was recorded in women from the time of implantation (McLachlan et al., 1987b). Although CG is considered to be the luteotrophic hormone of early pregnancy in primates, its role in the increased inhibin concentrations in marmoset monkeys is unclear. Since implantation does not occur in marmoset monkeys until days 11-12 after ovulation (Moore et al., 1985), the stimulus that promotes increased luteal production of inhibin occurred approximately 4 days before implantation. Furthermore, the present results show that the continued presence of the embryo message was not necessary to maintain increased inhibin production for the duration of the luteal phase. Of particular relevance is the fact that a significant increase in CG concentrations could not be detected in pregnant animals until day 17 (Hearn et al., 1988; Webley et al., 1991), some 9 days after the embryo stimulus. It is therefore possible that secretion of CG constitutes the 


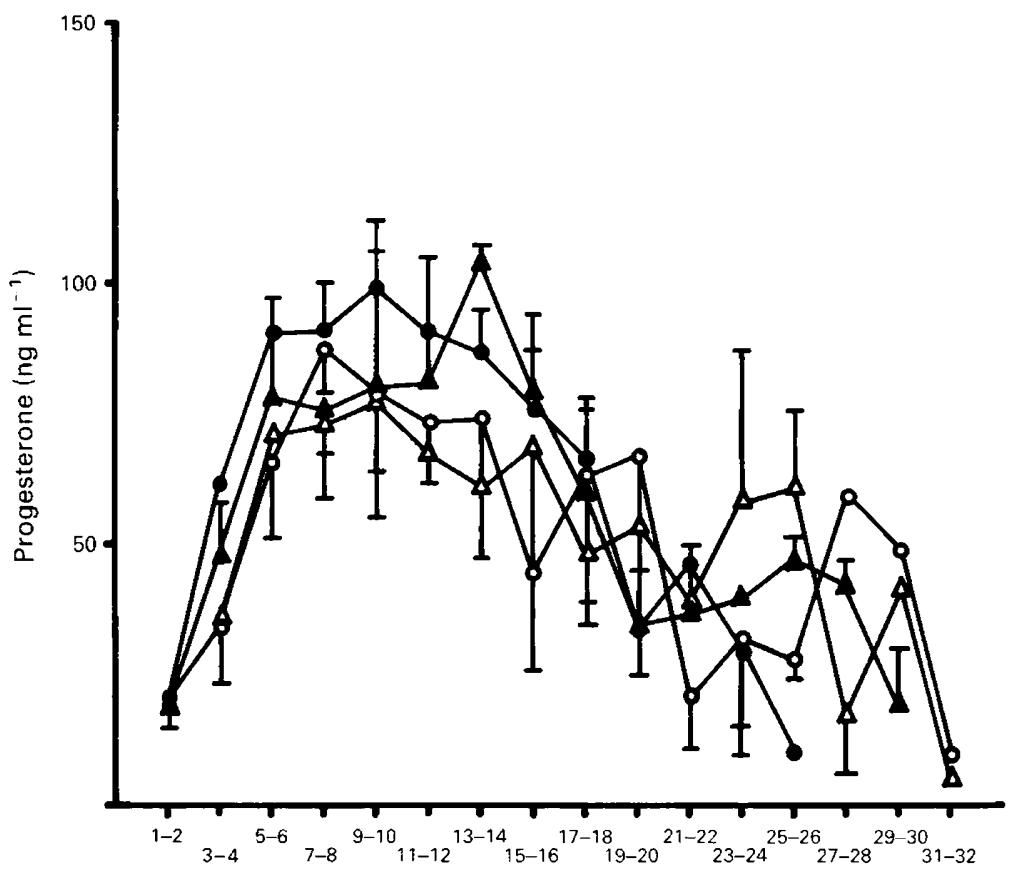

Day of the cycle from ovulation

Fig. 4. Mean ( \pm SEM) concentrations of progesterone in plasma samples of marmosets taken at different times in the cycle related to the day of ovulation before and after embryos were flushed from the uterus on day 5-6 $\triangle$ ), day $7(\bigcirc)$, day $8(\Delta)$ and day $9(\bullet)$ after ovulation.

early embryo message even though it cannot be detected by the bioassay until day 17. Alternatively, the embryo may produce another early message which can trigger an increase in luteal inhibin production. Several growth factors are produced by the pre-implantation embryo including transforming growth factors $\alpha$ (TGF- $\alpha$ ) and $\beta$ (TGF- $\beta$ ) (Werb, 1990) and these have been shown to influence inhibin production by rat granulosa cells (Findlay et al., 1990).

It was noted during the study that there was a large variation in luteal phase length of between 20 and 32 days. Previous evidence has shown that marmoset monkeys have follicular phases of $8 \cdot 25 \pm 0.3$ days and luteal phases of $19 \cdot 2 \pm 0.63$ days (Harlow et al., 1983). Similar follicular $(8.25 \pm 2.7$ days) and luteal $(21.5 \pm 2.2$ days) lengths were reported by Harding et al. (1982), although they described occasional cycles in which an extension of the luteal phase occurred. The variation reported in the present study may therefore not be unusual, although the presence of an embryo at the beginning of the luteal phase may have provided sufficient stimulus to delay luteal regression and extend the luteal phase in a proportion of the animals.

The physiological significance of high inhibin concentrations after conception in marmosets has yet to be established. In a recent study we demonstrated that a luteal phase increase in inhibin could not be detected using a two-site immunoreactive monoclonal antibody specific for the inhibin dimer (Knight et al., 1991) and that most of the inhibin that was detected in marmoset plasma by radioimmunoassay was therefore $\alpha$ subunit inhibin. It is known, however, that only dimeric inhibin acts at the pituitary to suppress selectively FSH production (see Knight, 1991). We are at present investigating the possibility that the inhibin $\alpha$-subunit may have a local action either within the ovary or at the level of the implanting embryo. Local actions of dimeric inhibin have recently been demonstrated in primates including the ability of inhibin to increase $\mathrm{LH}$-stimulated androgen 
production by human thecal cells (Hillier et al., 1991) and to modulate placental hCG production (Petraglia et al., 1989; Mersol-Barg et al., 1990).

The work was supported by an MRC/AFRC programme grant.

\section{References}

Abe, Y., Hasegawa, Y., Miyamoto, K., Yamaguchi, M., Andoh, A., Ibuki, Y. \& Igarashi, M. (1990) High concentrations of plasma immunoreactive inhibin during pregnancy in women. Journal of Clinical Endocrinology and Metabolism 71, 133-137.

Basseti, S.G., Winters, S.J., Keeping, H.S. \& Zeleznik, A.J. (1990) Serum immunoreactive inhibin levels before and after lutectomy in the cynomologus monkey (Macaca fascicularis). Journal of Clinical Endocrinology and Metabolism 70, 590-594.

Beard, A.J., Castillo, R.J., McLeod, B.J., Glencross, R.G. \& Knight, P.G. (1990) Comparison of the effects of crude and highly purified bovine inhibin $(\mathrm{Mr}$ 32000 ) on plasma concentrations of FSH and LH in chronically ovariectomised prepubertal heifers. Journal of Endocrinology 125, 21-30.

Davis, S.R., Krozowski, Z., McLachlan, R.I. \& Burger, H.G. (1987) Inhibin gene expression in the human corpus luteum. Journal of Endocrinology 115, R21-R23.

Findlay, J.K., Sai, X. \& Shukovski, L. (1990) Role of inhibin-related peptides as intragonadal regulators. Reproduction, Fertility and Development 2, 205-218.

Fraser, H.M., Robertson, D.M. \& De Kretser, D.M. (1989) Immunoreactive inhibin concentrations in serum throughout the menstrual cycle in the macaque: suppression of inhibin during the luteal phase after treatment with an LHRH antagonist. Journal of Endocrinology 121, R9-R12.

Harding, R.D., Hulme, M.J., Lunn, S.F., Henderson, C. \& Aitken, R.J. (1982) Plasma progesterone levels throughout the ovarian cycle of the common marmoset (Callithrix jacchus). Journal of Medical Primatology 11, 43-51.

Harlow, C.R., Gems, S., Hodges, J.K. \& Hearn, J.P. (1983) The relationship between plasma progesterone and the timing of ovulation and early embryonic development in the marmoset monkey (Callithrix jacchus). Journal of Zoology 201, 273-282.

Hearn, J.P. (1980) Endocrinology and timing of implantation in the marmoset monkey Callithrix jacchus. Progress in Reproductive Biology 7, 262-269.

Hearn, J.P., Hodges, J.K. \& Gems, S. (1988) Early secretion of chorionic gonadotrophin by marmoset embryos in vivo and in vitro. Journal of Endocrinology 119, 249-255.

Hillier, S.G., Wickings, E.J., Saunders, P.T.K., Dixson, A.F., Shimasaki, S., Swanston, I.A., Reichert, L.E., Jr \& McNeilly, A.S. (1989) Control of inhibin secretion by primate granulosa cells. Journal of Endocrinology $123,65-73$.

Hillier, S.G., Yong, E.L., Illingworth, P.L., Baird, D.T., Schwall, R.H. \& Mason, A.J. (1991) Effect of recombinant inhibin on androgen synthesis in cultured human thecal cells. Molecular and Cellular Endocrinology 75, R1-R6.
Hodges, J.K., Green, D.l., Cottingham, P.G., Sauer, M.J., Edwards, C. \& Lightman, S.L. (1988) Induction of luteal regression in the marmoset monkey (Callithrix jacchus) by a gonadotrophin-releasing hormone antagonist and the effects subsequent follicular development. Journal of Reproduction and Fertility 82, 743-752.

Knight, P.G. (1991) Identification and purification of inhibin and inhibin-related proteins. Journal of Reproduction and Fertility Supplement 43, 111-123.

Knight, P.G., Beard, A.J., Wrathall, J.H.M. \& Castillo, R.J. (1989) Evidence that the bovine ovary secretes large amounts of monomeric inhibin $\alpha$ subunit and its isolation from bovine follicular fluid. Journal of Molecular Endocrinology 2, 189-200.

Knight, P.G., Muttukrishna, S., Groome, N. \& Webley, G.E. (1991) Evidence that most of the radioimmunoassayable inhibin secreted by the corpus luteum of the common marmoset monkey is of a non-dimeric, biologically inactive form. Journal of Reproduction and Fertility Abstract Series 7, 121.

McLachlan, R.I., Robertson, D.M., Healy, D.L., Burger, H.G. \& De Kretser, D.M. (1987a) Circulating immunoreactive inhibin levels during the normal human menstrual cycie. Journal of Clinical Endocrinology and Metabolism 65, 954-961.

McLachlan, R.I., Healy, D.L., Robertson, D.M., Burger, H.G. \& De Kretser, D.M. (1987b) Circulating immunoreactive inhibin in the luteal phase and early gestation of women undergoing ovulation induction. Fertility and Sterility 48, 1001-1005.

McLachlan, R.I., Healy, D.L., Lutjen, P.L., Findlay, J.K., De Kretser, D.M. \& Burger, H.G. (1987c) The maternal ovary is not the source of circulating inhibin levels during human pregnancy. Clinical Endocrinology 27, 663-668.

McLachlan, R.I., Cohen, N.I., Vale, W.W., Rivier, J.E., Burger, H.G., Bremner, W.J. \& Soules, M.R. (1989) The importance of luteinizing hormone in the control of inhibin and progesterone secretion by the human corpus luteum. Journal of Clinical Endocrinology and Metabolism 68, 1078-1085.

Mayo, K.E., Cerelli, C.M., Spies, J., Rivier, J., Rosenfeld, M.G., Evans, R.M. \& Vale, W. (1986) Inhibin A-subunit cDNA from porcine ovary and human placenta. Proceedings of the National Academy of Sciences USA 83, 5849-5853.

Mersol-Barg, M.S., Miller, K.F., Choi, C.M., Lee, A.C. \& Kim, M.H. (1990) Inhibin suppresses human chorionic gonadotropin secretion in term, but not first trimester, placenta. Journal of Clinical Endocrinology and Metabolism 71, 1294-1398.

Moore, H.D.M., Gems, S. \& Hearn, J. P. (1985) Early implantation stages in the marmoset monkey (Callithrix jacchus). American Journal of Anatomy 172, 265-278. 
Petraglia, F., Sawechenko, P., Lim, A.T.W., Rivier, J. \& Vale, W. (1987) Localization, secretion and action of inhibin in human placenta. Science 237, 187-189.

Petraglia, F., Vaughan, J. \& Vale, W. (1989) Inhibin and activin modulate the release of gonadotropinreleasing hormone, human chorionic gonadotropin and progesterone from cultured human placental cells. Proceedings of National Academy of Sciences USA 86, 5114-5117.

Smith, K.B. \& Fraser, H.M. (1991) Control of progesterone and inhibin secretion during the luteal phase in the macaque. Journal of Endocrinology 128, 107-113.

Smith, K.B., Lunn, S.F. \& Fraser, H.M. (1990) Inhibin secretion in the common marmoset monkey. Journal of Endocrinology 126, 489-495.

Summers, P.M., Wennink, C.J. \& Hodges, J.K. (1985) Cloprostenol-induced luteolysis in the marmoset monkey (Callithrix jacchus). Journal of Reproduction and Fertility 73, 133-138.
Tabei, T., Ochiai, K., Terashima, Y. \& Takanashi, N. (1991) Serum levels of inhibin in maternal and umbilical blood during pregnancy. American Journal of Obstetrics and Gynecology 164, 896-900.

Tsonis, C.G., Hillier, S.G. \& Baird, D.T. (1987) Production of inhibin bioactivity by human granulosalutein cells: stimulation by $\mathrm{LH}$ and testosterone in vitro. Journal of Endocrinology 112, R I1-R 14.

Webley, G.E., Knight, P.G., Given, A. \& Hodges, J. K. (1991) Increased concentrations of immunoreactive inhibin during conception cycles in the marmoset monkey: suppression with an LHRH antagonist and cloprostenol. Journal of Endocrinology 128, 465-473.

Werb, Z. (1990) Expression of EGF and TGF- $\alpha$ genes in early mammalian development. Molecular Reproduction and Development 27, 10-15.

Received 22 August 1991 